\title{
The Effect of Financial Deepening on Economic Growth in Nigeria (1985 -2014)
}

\author{
Ifeanyi O. Nwanna (Ph.D) ${ }^{1}$, Chinyere Faith Chinwudu ${ }^{2}$ \\ Department of Banking \& Finance, Nnamdi Azikiwe University, Awka
}

\begin{abstract}
This research work examines financial deepening and economic growth in Nigeria from 1985 to 2014. It focused on the impact of stock market and bank deepening variables such as money supply, market capitalization, private sector credit and financial savings have on economic growth of Nigeria. Stock market provides the avenue through which long term fund could be raised for investment project. It is reputed to perform critical functions, which promote economic growth and prospects of the economy. The study adopted the supply leading hypothesis. The study used annual time series data for 1985 to 2014 obtained from the Central Bank of Nigeria statistical bulletin. The ordinary least square (OLS) econometric techniques were employed in which variations in the dependent variable, economic growth, measured by gross domestic product growth rate were regressed on money supply ratio to gross domestic product, private sector credit ratio to gross domestic product, market capitalization ratio to gross domestic product and financial saving ratio to gross domestic product using time series data from 1985 to 2014. The result of the analysis reveals that both bank based and stock market financial deepening proxies has significant and positive effect on economic growth and that the banking sector and stock market in Nigeria has an important role in the process of economic growth. Based on the findings there should be improvement by encouraging more participation in the stock market. Easing restrictions on international capital and entry into stock market to ensure more companies are listed.
\end{abstract}

Keywords: Economic Growth, Financial Deepening, Financial Market, Private Sector Credit, Supply Leading Hypothesis

\subsection{Background of the Study}

\section{Introduction}

Financial deepening is to improve economic conditions through increased competitive efficiency within financial markets thereby indirectly benefiting non-financial sectors of the economy. Financial deepening also helps in increasing the provision and choices of financial services which would come through its financial infrastructure. Nzotta and Okereke (2009)[1] ascertain that financial deepening is the ability of financial institutions in an economy to effectively mobilize savings for investment purposes. Financial deepening vigorously attracts the reservoir of savings and idle funds and allocates same to entrepreneurs, business, households and government for investments projects and other purposes with a view of returns which forms the basis for economic growth.

The growing importance of stock market and banks around the world has recently opened a new avenue of research into the relationship between financial deepening and economic growth (Arestis, Demetriades and Luintel, 2001)[2]. The general idea that economic growth is related to financial deepening was first highlighted by Schumpeter in 1911.(Okoli 2010)[3]. The financial deepening role in economic growth has received much attention. However, the focus has been almost entirely on bank based financial deepening measures, while ignoring the possible impact of stock market development.

Financial reforms have been a regular feature of the Nigeria financial system. The Central Bank of Nigeria $(\mathrm{CBN})$ has been trying hard to ensure that the financial sector in Nigeria maintain a considerable depth and remain liquid with a view to competing effectively within the global financial market. The reforms have evolved in response to the challenges posed by developments in the system such as systemic crisis, globalization, technological innovation and financial crisis. The reforms often seek to act proactively to strengthen the system, thus, there is need to deepen the financial sector and reposition it for growth and integration into the global financial system in conformity with international best practices.

\section{Statement of Problem}

Over the past few decades, financial deepening and economic growth has attracted significant attention from finance and development experts and has been debated extensively. This debate can be characterized into two main theoretical propositions: the supply-leading hypothesis (Neusser \& Kugler, 1998)[4] and demandleading hypothesis (Patrick, 1966[5]; Ireland, 1994[6]). Supply leading hypothesis suggest that financial deepening spurs growth. The hypothesis contends that the development of financial market can create and expand liquidity, mobilize savings and promote the growth of an economy. The demand following hypothesis 
suggest that any early efforts to deepen the financial system might lead to a waste of resources. It is argued that financial deepening is merely an outcome of growth in the real sector of the economy which could be allocated to more useful purposes in the early stages of growth. (Ireland, 1994[6]; Odiambho, 2004[7]; Wadud, 2005[8]).

Financial deepening plays an important role in determining the growth of an economy. It broadens its resource base, raises the capital needed to stimulate investment through savings and credit, and boost the overall productivity. The design and implementation of effective interventions and programs in the Nigeria banking sector and stock market has led to a continued growth in financial assets, with a direct contribution from financial intermediaries. However, economic growth in Nigeria, whether as a result of financial deepening or other growth factors has been fluctuating over the last decade with rate as low as 0.5 in 1999. Therefore, it is of importance to assess the banking sector and stock market deepening effects on economic growth in Nigeria.

The Nigeria economy is one of the largest in Africa, but empirical research have given little emphasis on the nature of financial deepening and economic growth bearing in mind the recent downturn in the financial market and how it affects the real sector of the economy and this have generated a lot of controversies and further research needs to be carried out on the nature of the relationship between the financial sector and economic growth.

\section{Objectives of the Study}

The main objective of this study is to examine the effect of financial deepening on economic growth using time series data set in Nigeria from 1985 to 2014.

Specifically the study seeks to:

1. Examine the effect of money supply on economic growth in Nigeria.

2. Determine the effect of private sector credit on economic growth in Nigeria.

3. Assess the effect of market capitalization on economic growth in Nigeria.

4. To examine the effect of financial savings on economic growth in Nigeria.

\subsection{Research Questions}

To examine the topic of this study, the following research questions are posed:

1. To what extent is the effect of money supply on economic growth in Nigeria?

2. How does private sector credit influence economic growth in Nigeria?

3. To what extent has market capitalization impact on economic growth in Nigeria?

4. To what level has the financial savings stimulated economic growth in Nigeria?

\subsection{Research Hypotheses}

This study is designed to examine the effect of financial deepening on economic growth in Nigeria. The hypotheses therefore postulated as follows:

1. $\mathrm{H}_{\mathrm{o}}$ - Money supply has no significant effect on economic growth in Nigeria.

2. $\mathrm{H}_{\mathrm{o}}$ - Private sector credit has no significant effect on economic growth in Nigeria.

3. $\mathrm{H}_{\mathrm{o}}$ - Market capitalization has no significant effect on economic growth in Nigeria.

4. $\mathrm{H}_{\mathrm{o}}$ - Financial savings has no significant effect on economic growth in Nigeria.

\subsection{Scope of the Study}

This research work examined financial deepening and economic growth from 1985 to 2014. The period covered by this study (1985 to 2014) is the grey, boom and doom periods of capital market development in Nigeria. Within this period great stripes were made in the infrastructures, institutions and regulations that pertain to the Nigerian Capital market. This study is not a comparison of the Nigeria financial sector economic deepening with those of other countries. This is based on the fact that focusing on a single country; it will be possible to keep substantial variability within the sample.

\subsection{Limitations of the Study}

This study was restricted to a period of thirty years from 1985 to 2014 . The choice of data range is due to the availability of data and also covers the purpose for which the research work is intended. The financial deepening indicators which the researcher used were constructed proxies which might not perfectly replicate the functions of financial deepening. However, financial inclusiveness should be all embracing and in practice perfect measures do not exist. The study deals with secondary data obtained from Central bank of Nigeria Statistical bulletin, which may contain some measurement errors. This may likely affect the robustness of our findings. 
The Effect of Financial Deepening on Economic Growth in Nigeria (1985 -2014).

\subsection{Significance of the Study}

The research is significant to the following stakeholders:

Policy Makers: The effect of financial deepening on economic growth is important as this will inform and update Nigeria policy makers to give priority to all policies that affect financial deepening and find ways through which financial deepening can be made more effective and efficient. This study will help formulate policies capable of enhancing the development of the financial sector. According to Ndebbio (2000)[9], the financial sector is the conduit through which financial deepening is manifested.

Investors: The result of the study would be of benefit to investment analysts and investors in examining the effectiveness of financial deepening and thus evaluating the option available for accessing long-term, shortterm, non-debt financial capital which enables investors to avoid over reliance on debt financing.

Researchers: Individuals or groups who want to study the effect of financial deepening on economic growth will find this work very useful because it carefully analyzed the impact of financial deepening on economic growth and proffered solutions on how financial deepening can be made more efficient. As a matter of fact, it adds to already existing empirical literature in the context of Nigeria.

Financial Institution: This study will help the financial Institution operators to understand the dynamics in financial policies thereby equipping them to participate in a more sustainable manner in the financial system. The financial institutions are the channels through which financial deepening is implemented to foster economic growth.

\section{Review of Related Literature}

\subsection{Conceptual Classification}

The finance led theory anchors this work, which postulates that financial deepening can enhance economic growth. The question arises as to what kind of financial deepening measures are most appropriate, bank based or stock market. Empirical literature on the impact of financial deepening on economic growth had mainly used bank based measures of financial deepening. (Agu and Chukwu, 2008[10] ; Nzotta and Okereke, 2009[1] ; Victor and Samuel, 2013[11]).

Haizinga (2000)[12], however, argued that the stock market is better as a means of financing growth, as it provides a greater opportunities for competition, thereby encouraging entrepreneurship. In principle, the stock market is expected to accelerate economic growth, by providing a boost to domestic savings and increasing the quantity and the quality of investment. The market is expected to encourage savings by providing individuals with an additional financial instrument that may better meet their risk preferences and liquidity needs. Better savings mobilization may increase the saving rate. The stock market also provides an avenue for growing companies to raise capital at lower cost. In addition, companies in countries with developed stock market are less dependent on bank financing, which can reduce the risk of a credit crunch. (Osho 2014)[13].

Economic growth is generally agreed to indicate development in an economy, because it transforms a country from a five percent saver to a fifteen percent saver. Thus it is argued that for stock market and bank financing to contribute or impact on the economic growth in Nigeria, it must operate efficiently(Bashiru, 2013[14]). Levine (2002)[15], argued that bank and stock markets provide financial services which are essential for the growth of a country and is of the opinion that the services provided by bank and stock market may be complementary.

Demand - Following Hypothesis: The demand-following view of the deepening of the financial markets is merely a lagged response to economic growth (growth generates demand for financial products). This implies that any early efforts to develop financial markets might lead to a waste of resources which could be allocated to more useful purposes in the early stages of growth. As the economy advances, this triggers an increased demand for more financial services and thus leads to greater financial deepening. The demand-following pattern should be expected to establish a causality that runs from growth to finance at a later stage of development. More advanced economies may accordingly be expected to exhibit this direction of causality (Agu \& Chukwu, 2008)[10]

Importance of Financial Deepening: According to Jalilian and Kirkpatrick (2005)[16] there are some clear links of financial deepening with economic growth in developing countries. Empirical analysis confirms the common finding of a positive relationship between financial deepening and growth, noticeably for poorer developing countries. Finance as a well established supply leading character i.e. the level of financial deepening and stock market liquidity each exerts an independent, positive influence on economy growth. Financial services and financial deepening (as measure by the size of the intermediary sector) stimulates economic growth by increasing the rate of capital accumulation and by improving the efficiency with which economies use that capital in the current period as well as in the future. 
The Effect of Financial Deepening on Economic Growth in Nigeria (1985 -2014).

Financial deepening can also lead to greater efficiency of financial intermediation (e.g. via intermediation of greater amounts of domestic savings and investment cycles) and thereby greater stability. The diversified funding base of financial institutions has played a role in cushioning the impact of a global credit (wholesale funding) crunch on domestic financial intermediation. (Sahoo, 2013)[17].

\subsection{Theoretical Framework}

Literature on the relationship between financial deepening and economic growth have shown conflicting reports. Studies like Waqabaca (2004)[18], Azege (2004)[19], Nzotta and Okereke (2009)[1], Sulaiman, Oke and Azzez (2012)[20] reported that there is a positive relationship between financial deepening and economic growth. In the relevant literature, there have been a number of empirical studies that indicate a negative association between financial deepening and economic growth. Such studies include Ardic and Damar (2006)[21], Guryay, Safakli and Tuzel (2007)[22].

Several studies with mixed results have been conducted across countries to investigate the relationship between financial deepening and economic growth. Some studies have used developed and developing crosscountries data sets (King and Levine, 1993)[23]. Other studies have used a sub-regional African approach (Nguena and Abimbola, 2013[24] ; Ndebbio, 2004[9]). In individual African countries context such as South Africa (Jail, Wahid and Shahbaz, 2010[25]) ; Nigeria ( Nzotta and Okereke 2009[1]) findings suggested mixed results depending on financial deepening indicators employed. Several studies have mainly focused on determining the direction of causality between financial deepening variables and economic growth with different conclusions on how both concepts affect each other (Odhiambo, 2004[7] ; Onuonga, 2014[26]).

According to Nwaogwugwu (2008)[27], Financial deepening refers to the increased provision of financial services with a wider choice of services geared towards the development of all levels of society. The World Bank (2000)[28] further contends that financial deepening encompasses the increase in the stock of financial assets. From this perspective, financial deepening implies the ability of financial institutions in general, to effectively mobilize financial resources for development. This view accepts the fact that a financial system's contribution to the economy depends on the quality and quantity of its services and the efficiency with which it performs them.

The size of the financial sector is usually measured by two basic quantitative indicators: "monetization ratio" and "intermediation ratio". Whereas monetization ratio includes money-based indicators like money supply ratio to gross domestic product, intermediation ratio consists of indicators concerning to bank-based measures like private sector credit ratio to gross domestic product and capital market-based measures such as market capitalization ratio to gross domestic product (Ndebbio, 2004)[9].

Financial Deepening and Economic Growth: Economic growth means the growth in a nation's real gross domestic product (an increase in a nation's output of goods and services) or the physical expansion of the nation's economy. (Antwi, Mills and Zhao, 2013)[29]. Economic growth can be illustrated as an upbeat change on the output of a nation's manufacturing goods and services, stretching over a certain period of time (Kanu \& Ozurumba, 2013)[30].

In the view of Ndebbio (2004)[9], financial deepening means an increase in the supply of financial assets in the economy. Therefore, the sum of all the measures of financial assets gives us the approximate size of financial deepening. That means that the widest range of such assets as broad money, value of shares in the stock market, money market funds, etc, will have to be included in the measure of financial deepening. In his study, Ndebbio (2004)[9] note that if the increase in the supply of financial assets is small, it means that financial deepening in the economy is most likely to be shallow, but if the ratio is big it means that financial deepening is likely to be high. He further went on to stressed that developed economies are characterized by high financial deepening, meaning that the financial sector in such countries has had significant growth and improvement, which has, in turn, led to the growth and development of the entire economy. Furthermore, $\mathrm{He}$ suggested that the financial sector is the conduit through which financial deepening is manifested.

According to Fisher (2001)[31], financial deepening refers to the greater financial resource mobilization in the formal financial sector and the ease in liquidity constraints of banks and enlargement of funds available to finance projects.

The Department for International Development -DFID (2004)[28] defined the financial sector of an economy as the wholesale, retail, formal and informal institutions in an economy offering financial services to consumers, businesses and other financial institutions. It therefore broadly includes everything from banks, stock exchanges, insurers, credit unions, microfinance institutions and money lenders. DFID (2004)[28] further outlined the ways in which the financial sector can be adjudged to be developed or to have deepened and these include improvement in the efficiency and competitiveness of the sector, the range of financial services that are available may increase, the extent to which capital is allocated by private sector financial institutions to private sector enterprises responding to market signals (rather than government directed lending 
by state owned banks) may increase, the regulation and stability of the financial sector may improve and more of the population may gain access to financial services.

The financial institution has the potential to boost savings and channel it to deficit sector of the economy through extension of credit. This requires a high degree of financial intermediation in the financial sector. Such a come together of the deficit and surplus spending units is likely to result in more deepening of the financial system. (Ghani,2002)[32].

\subsection{Empirical Literature}

Odiambho (2004)[7] investigates the role of financial development on economic growth in South Africa. The study uses three proxies of financial development namely the ratio of $\mathrm{M}_{2}$ to GDP, the ratio of currency to narrow money and the ratio of bank claims on the private sector to GDP against economic growth proxies by real GDP per capita. He employed the Johansen-Juselius co-integration approach and vector error correction model to empirically reveal overwhelming demand-following response between financial development and economic growth. The study totally rejects the supply leading hypothesis.

Fatima (2004)[33] examined the casual relationship between financial deepening and economic growth in Morocco for the periods, 1990-2000. The ratio of liquid liabilities (M3) to GDP, ratio of domestic credit provided by the banking sector to GDP and domestic credit were the financial debt indicators used. Using the granger causality test, the study found a short - run relationship between financial deepening and economic growth.

Ndebbio (2004)[9] study financial deepening and economic growth: evidence from selected subSaharan African countries using the ratio of money supply to GDP and growth rate per capital real money balances as indicators of financial deepening. The study found positive and statistically significant impact on growth rate in per capital real money balances on real per capital GDP growth.

Ang (2007)[34] examined to what extent financial development contributed to output expansion during the period 1960 to 2013. Using augmented neoclassical growth framework to provide an evaluation of the impact of financial sector development on economic development and the Autoregressive Distributed Lag Model (ARDL) bounds procedure, the researcher found that aggregate output and its determination are co integrated in the long run, suggesting that financial development whereas the accumulation of public capital appears to curtail output expansion in the long run.

Adu, Marbuah and Mensah (2013)[35] studied financial deepening and economic growth in Ghana: The study investigate the long-run growth effects of financial deepening in Ghana using one indicator at a time among a set of controls variable. The financial deepening variables used are private sector credit ratio to GDP, money supply ratio to GDP, total domestic credit to GDP and total bank deposit liabilities to GDP and set of control variables namely inflation rate, trade openness, real gross government expenditure. The study test the variable using the ordinary least square method and found out that all the measure of financial deepening have a positive effect on economic growth in Ghana except broad money supply to GDP.

Luqman (2014)[36] studied the financial deepening and economic growth in Pakistan, the result show that foreign direct investment, inflation, economic growth and financial deepening proxy by credit to private sector are co integrated hence long run relationship exists among them. The study test the variable using the vector error correction model and found out that the level of financial deepening in Pakistan has remained relatively low.

Shittu (2012)[37] examines the impact of financial intermediation on economic growth in Nigeria with time series data from 1970 to 2010. Employing co integration test and error correction model, he finds that financial intermediation has a significant impact on economic growth in Nigeria. Sulaiman and Azzez (2012)[38] critically explore the effect of financial liberalization on the economic growth in developing nations with its assessment focusing on Nigeria with annual time series data from 1987-2009. The study employs cointegration and error correction model (ECM) by making Gross Domestic Product as a function of lending rate, exchange rate, inflation rate, financial deepening $\left(\mathrm{M}_{2} / \mathrm{GDP}\right)$ and degree of openness as its financial liberalization indices. Co-integration result confirms the existence of long run equilibrium relationship while the ECM results show a very high $\mathrm{R}^{2}$ in both the over-parameterized model $(95 \%)$ and parsimonious model $(91 \%)$. The study therefore concludes that financial liberalization has a growth-stimulating effect on Nigeria.

Onwumere, Ibe, Ozoh and Mounanu (2012)[39] examines the impact of financial deepening on economic growth in Nigeria for the period of 1992 - 2008 and adopted the supply-leading hypothesis using variables such as broad money velocity, money stock diversification, economic volatility, market capitalization and market liquidity as proxies for financial deepening and gross domestic product growth rate for economic growth. They found that broad money velocity and market liquidity promote economic growth in Nigeria while money stock diversification, economic volatility and market capitalization did not within the period studied. The study recommended that government policy should be geared towards increasing money supply and promoting 
efficient capital market that will enhance overall economic efficiency, create and expand liquidity, mobilize savings, enhance capital accumulation, transfer resources from traditional sectors to growth inducing sectors.

Agu and Chukwu (2008)[10] studied financial deepening and economic growth in Nigeria from the period of 1970 to 2005 . The study used only bank based financial deepening proxies. Financial deepening means an increase in asset and providing level of financial services to the economy. The total amount of financial assets will constitute an optimal measure of financial deepening.

Adu, Marbuah and Mensah (2013)[35] investigate the long run effect, financial deepening has on the Ghana economy, using a time series data for 14 years period 1998 to 2011. Their study used private sector credit ratio to GDP, money supply ratio to GDP, total domestic credit ratio, total bank liabilities ratio and a set of control variables such as trade openness, inflation rate and real gross government expenditure. The study, although useful in the use of more than one measure of financial deepening and the use of control variables, the number of observation of their data points is insufficient to obtain a statistically significant result for the individual variables. The researcher failed to apprehend the fact that the time span of the study draws into question the validity of the finding, as they could be spurious. Econometric theories suggest a minimum 15 year's time series data as a measure of avoiding spurious result in a study.

\subsection{Research Design}

\section{Research Methodology}

The study used expo - facto research design. This is as a result of the fact that the data used are already established data and cannot be manipulated by the researcher.

\subsection{Data Sources}

The data required for this analysis are time series data. In order to facilitate time series analysis, the data were sourced from the Central bank of Nigeria (CBN) statistical bulletin, Nigerian Stock Exchange (NSE) fact books, published journals, seminars papers, Central bank of Nigeria bullion, unpublished write-up.

\section{Method of Data Collection}

The data used in this research consists of secondary data to achieve the objectives of the study.

\subsection{Techniques of Analysis}

The results generated from the study are analyzed using both descriptive and analytical techniques. The analytical techniques employed are based from the result of the regression analysis using the ordinary least (OLS) approach. Analysis is done using economic view (E-view) statistical package.

\subsection{Model Specification}

The specification of the model involves the determination of the dependent and independent variables that are included in the model. It expresses the mathematical relationship that exists between the dependent and the independent or explanatory variables. Following a detailed review of previous studies and improving upon the theory, economic growth $\mathrm{Y}_{\mathrm{t}}$ is expressed as a function of financial deepening, $\mathrm{F}_{\mathrm{t}}$, and a set of control variable, $\mathrm{Z}_{\mathrm{t}}$. as amplified in the works of Adu, Marbuah and Mensah (2013)[35], Victor and Samuel (2013)[11]. This is expressed as below;

$$
Y_{t}=f\left\{F_{t}, Z_{t}\right\} \ldots \ldots
$$

Improving upon the theoretical postulate in equation 1 above, the equation will be expanded to accommodate the indicators of financial deepening and other growth determinants.

Thus, $\mathrm{Y}_{\mathrm{t}}=\alpha+\alpha \mathrm{F}_{\mathrm{t}}+\alpha \mathrm{Z}_{\mathrm{t}}+\mathrm{u}$

This research work adopts the model of Victor and Samuel (2013)[11] with slight modifications. In his model, the researcher expressed economic growth as a function of financial deepening measured by money supply and other set of control variables such as liquidity ratio, minimum capital base and interest rate.

To examine the impact of financial deepening on economic growth in Nigeria, the study used the multivariate model below:

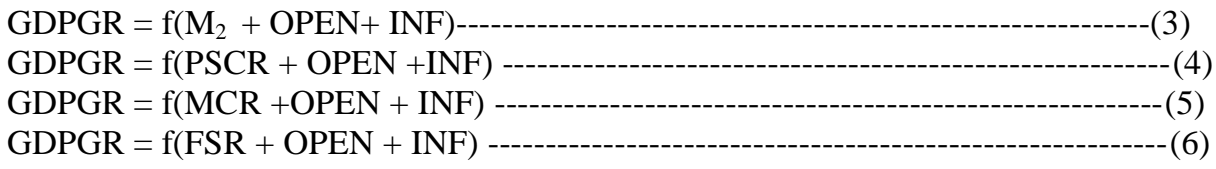

These models will be represented in a log-linear econometric format to obtain the coefficients of the elasticity of the variables, while reducing the possible impact that any outlier may have thus;

Model 1

GDPGR $_{\mathrm{t}}=\mathrm{a}_{0}+\mathrm{a}_{1} \mathrm{M}_{2 \mathrm{t}}+\mathrm{a}_{2} \mathrm{OPEN}_{\mathrm{t}}+\mathrm{a}_{3} \mathrm{INF}_{\mathrm{t}}+\mathrm{U}_{\mathrm{t}}$

Model 2

GDPGR $_{\mathrm{t}}=\mathrm{a}_{0}+\mathrm{a}_{1} \mathrm{PSCR}_{\mathrm{t}}+\mathrm{a}_{2} \mathrm{OPEN}_{\mathrm{t}}+\mathrm{a}_{3} \mathrm{INF}_{\mathrm{t}}+\mathrm{U}_{\mathrm{t}}$ 
Model 3

GDPGR $_{\mathrm{t}}=\mathrm{a}_{0}+\mathrm{a}_{1} \mathrm{MCR}_{\mathrm{t}}+\mathrm{a}_{2} \mathrm{OPEN}_{\mathrm{t}}+\mathrm{a}_{3} \mathrm{INF}_{\mathrm{t}}+\mathrm{U}_{\mathrm{t}}$

\section{Model 4}

$\mathrm{GDPGR}_{\mathrm{t}}=\mathrm{a}_{0}+\mathrm{a}_{1} \mathrm{FSR}_{\mathrm{t}}+\mathrm{a}_{2} \mathrm{OPEN}_{\mathrm{t}}+\mathrm{a}_{3} \mathrm{INF}_{\mathrm{t}}+\mathrm{U}_{\mathrm{t}}$

$\begin{array}{lll}\text { Where: } & \\ \text { GDPGR }= & \text { Gross Domestic Product Growth Rate } \\ \mathrm{M}_{2}= & \text { Ratio of money supply to GDP } \\ \text { PSCR }= & \text { Ratio of private sector credit to GDP } \\ \text { MCR }= & \text { Ratio of Market Capitalization to GDP } \\ \text { FSR } & = & \text { Ratio of Financial Saving to GDP } \\ \text { OPEN } & = & \text { Trade Openness } \\ \text { INF } & = & \text { Inflation rate } \\ \mathrm{a}_{0} & = & \text { constant } \\ \mathrm{U} & = & \text { Error term } \\ \mathrm{t} & = & \text { Time Trend }\end{array}$

\subsection{A Priori Expectation}

This refers to the supposed relationship between and or among the dependent or independent variables of the model as determined by the postulations of endogenous theory. Here, the researchers determine whether the variable conforms to expectations or whether there is a deviance. The table below summarizes the a priori expectation of the parameters:

Table 5.1 Table of a priori expected signs Expected Sign of the Independent Variables in the Model

\begin{tabular}{|l|l|l|l|}
\hline SYMBOL & VARIABLES & $\begin{array}{l}\text { EXPECTED } \\
\text { SIGNS }\end{array}$ & $\begin{array}{l}\text { RESEARCHER WHO HAVE EMPLOYED } \\
\text { THEM }\end{array}$ \\
\hline M2 & Money Supply ratio to GDP & Positive (+) & $\begin{array}{l}\text { Nzotta and Okereke(2009); Victor and Samuel } \\
\text { (2014) .George et al (2013) }\end{array}$ \\
\hline PSCR & Credit to Private Sector ratio to GDP & Positive(+) & Nzotta and Okereke(2009); Adu et al (2013). \\
\hline MCR & Market Capitalization ratio to GDP & Positive (+) & $\begin{array}{l}\text { Okoli (2010), Wadud (2005), Owumere et al } \\
\text { (2012). }\end{array}$ \\
\hline FSR & Financial Savings ratio to GDP & Positive (+) & Nzotta and Okereke (2009) \\
\hline
\end{tabular}

Source: The researcher.

\section{Data Presentation And Analysis}

\subsection{Data Presentation}

The analysis is based on economic criteria and statistical criteria. Table 6.1 present the data for gross domestic product (GDPGR) at growth rate, money supply ratio to gross domestic product, Private sector credit ratio to gross domestic product, market capitalization ratio to gross domestic product, financial saving ratio to gross domestic product, trade openness (total import and export as a ratio to gross domestic product) and inflation rate for the period of 1985 to 2014.

Table 6.1: Gross domestic product, Money supply, Private sector credit, Market capitalization, financial saving,

Trade openness and Inflation rate from $1985-2014$

\begin{tabular}{|c|c|c|c|c|c|c|c|}
\hline YEAR & $\begin{array}{l}\text { GDP at } \\
\text { Growth } \\
\text { Rate } \\
(\%)\end{array}$ & $\begin{array}{l}\text { Money } \\
\text { Supply as a } \\
\text { Ratio of GDP } \\
(\%)\end{array}$ & $\begin{array}{l}\text { Private Sector } \\
\text { Credit as a } \\
\text { Ration of GDP } \\
(\%)\end{array}$ & $\begin{array}{l}\text { Market } \\
\text { Capitalization } \\
\text { as a Ratio of } \\
\text { GDP }(\%)\end{array}$ & $\begin{array}{l}\text { Financial } \\
\text { Savings as a } \\
\text { Ratio of GDP } \\
(\%)\end{array}$ & $\begin{array}{l}\text { Inflat } \\
\text { ion } \\
(\%)\end{array}$ & $\begin{array}{l}\text { Trade } \\
\text { Openness } \\
(\%)\end{array}$ \\
\hline 1985 & -7.8 & 16.6 & 9.7 & 4.90 & 9.30 & 1.00 & 13.97 \\
\hline 1986 & -8.8 & 17.7 & 11.3 & 5.05 & 10.35 & 13.7 & 11.07 \\
\hline 1987 & -10.8 & 14.3 & 10.9 & 4.5 & 9.67 & 9.7 & 24.96 \\
\hline 1988 & 7.5 & 14.6 & 10.4 & 3.80 & 8.83 & 61.2 & 19.98 \\
\hline 1989 & 6.5 & 12.0 & 8.0 & 3.35 & 6.23 & 44.7 & 23.22 \\
\hline 1990 & 12.8 & 11.2 & 7.1 & 4.96 & 6.27 & 3.6 & 47.35 \\
\hline 1991 & 0.6 & 13.8 & 7.6 & 4.23 & 6.92 & 23 & 38.67 \\
\hline 1992 & 0.4 & 12.7 & 6.6 & 3.56 & 6.30 & 48.8 & 39.85 \\
\hline 1993 & 2.1 & 15.2 & 11.7 & 4.36 & 7.80 & 61.3 & 35.28 \\
\hline 1994 & 0.9 & 16.5 & 10.2 & 4.74 & 7.93 & 76.8 & 26.35 \\
\hline 1995 & -0.3 & 9.9 & 6.2 & 6.20 & 3.73 & 51.6 & 58.67 \\
\hline 1996 & 5.0 & 8.6 & 5.9 & 7.09 & 3.34 & 14.3 & 46.43 \\
\hline 1997 & 2.8 & 9.9 & 7.5 & 6.73 & 4.24 & 10.2 & 49.83 \\
\hline
\end{tabular}


The Effect of Financial Deepening on Economic Growth in Nigeria (1985 -2014).

\begin{tabular}{|c|c|c|c|c|c|c|c|}
\hline 1998 & 2.7 & 12.2 & 8.8 & 6.58 & 5.01 & 11.9 & 39.84 \\
\hline 1999 & 0.5 & 13.4 & 9.2 & 6.41 & 5.93 & 0.2 & 43.84 \\
\hline 2000 & 5.3 & 13.1 & 7.9 & 7.03 & 5.74 & 14.5 & 43.65 \\
\hline 2001 & 4.4 & 18.4 & 11.1 & 9.61 & 7.08 & 16.5 & 46.79 \\
\hline 2002 & 3.8 & 19.3 & 11.9 & 9.81 & 7.60 & 12.2 & 41.78 \\
\hline 2003 & 10.4 & 19.7 & 11.1 & 13.71 & 6.61 & 23.8 & 52.13 \\
\hline 2004 & 33.7 & 18.7 & 12.5 & 18.51 & 6.99 & 10 & 57.75 \\
\hline 2005 & 3.4 & 18.1 & 12.6 & 19.85 & 9.01 & 11.6 & 68.77 \\
\hline 2006 & 8.2 & 20.5 & 12.3 & 27.58 & 9.37 & 8.5 & 56.20 \\
\hline 2007 & 6.8 & 24.8 & 17.8 & 63.81 & 13.04 & 6.6 & 59.16 \\
\hline 2008 & 6.3 & 33.0 & 28.5 & 39.36 & 16.95 & 15.1 & 63.19 \\
\hline 2009 & 6.9 & 38.0 & 36.7 & 28.36 & 23.25 & 13.9 & 54.52 \\
\hline 2010 & 7.8 & 20.4 & 18.7 & 18.30 & 10.98 & 18.8 & 35.65 \\
\hline 2011 & 4.9 & 19.2 & 16.9 & 16.24 & 10.33 & 10.3 & 39.61 \\
\hline 2012 & 4.3 & 19.5 & 20.6 & 20.79 & 11.33 & 12.0 & 33.46 \\
\hline 2013 & 5.4 & 18.9 & 19.7 & 23.78 & 10.79 & 8.0 & 29.48 \\
\hline 2014 & 6.3 & 19.9 & 19.2 & 18.95 & 13.49 & 8.0 & 20.75 \\
\hline
\end{tabular}

SOURCE: Compiled from data obtained from Central Bank of Nigeria Statistical Bulletin 2014

The growth in the market manifested in the phenomenal increase in market capitalization from 4.9 percent in 1985 to 63.81 percent in 2007. It can be observed from Table 6.1 that the money supply ratio rose from 9.7 percent in 1985 to 36.7 percent in 2009 and decreased to 19.7 percent in 2014 . The ratio of financial savings to gross domestic product increase to a high of 23.25 percent in 2009 but reduce gradually thereafter to 13.45 percent in 2014.

In 1985 the growth rate shows a negative of -7.8 and gradually increases to 7.5 percent in 1988 after the introduction of the structural adjustment programme of 1986. This later rose above the pre-reform levels and remained positive until 1995 when it recorded a negative of -0.3 . The economy witnessed high growth rates in gross domestic product of 33.7 percent in 2004 before it decline to 3.4 percent in 2005 followed by a gradual recovery to 6.3 percent in 2014. A key factor responsible for the negative growth rates from 1985 - 1987 periods was the low performance of the oil sector and the collapse of the international oil prices.

Table 6.1 reveals that inflation rate rose to a high of 76.8 percent in 1994 and to 0.2 in 1999 . The inflation rate has been experiencing fluctuation from 1985 to 2014. Trade openness rose from 13.97 percent in 1985 to 68.77 percent by 2005 .

\subsection{Descriptive Statistic}

The study conducted the descriptive statistics of the relevant variables involved. Table 6.2 illustrates vividly these statistics. It shows total number of observations, mean, median, maximum, minimum, standard deviation and the sum of mean deviation. The dependent variables which is gross domestic product growth rate shows the low of -10.8000 which was observed in 1987 and shows the high of 33.7 which was observed in 2004. The mean values of the dependent variables is 4.400000 and the standard deviation is 7.595234 this implies that there was high fluctuation in gross domestic product growth rate for the years.

It can be observed from Table 6.2 that all the variables have positive average values (means). The minimal deviation of the variables from their means as shown by the standard deviation gives indication of growth rate (fluctuation) of these variables over the period. It can be observed also that all the variables show signs of positive skewness.

Table 6.2: Descriptive Statistic for the Variables of the Study

\begin{tabular}{|l|l|l|l|l|l|l|l|}
\hline & FSR & GDPGR & INF & M2 & MCR & OPEN & PSCR \\
\hline Mean & 8.813667 & 4.400000 & 20.72667 & 17.33667 & 13.73833 & 24.36000 & 12.95333 \\
\hline Median & 7.865000 & 4.650000 & 12.95000 & 17.15000 & 7.060000 & 13.840000 & 11.10000 \\
\hline Maximum & 23.25000 & 33.70000 & 76.80000 & 38.00000 & 63.81000 & 68.77000 & 36.70000 \\
\hline Minimum & 3.340000 & -10.80000 & 0.200000 & 8.600000 & 3.350000 & 11.070000 & 5.900000 \\
\hline Std. Dev. & 4.075660 & 7.595234 & 19.94081 & 6.289426 & 13.19892 & 13.51701 & 6.879341 \\
\hline Skewness & 1.650449 & 1.454119 & 1.484466 & 1.530336 & 1.126956 & 1.541550 & 1.788640 \\
\hline Kurtosis & 6.626922 & 9.123117 & 4.005551 & 5.975949 & 8.122137 & 6.332279 & 6.313256 \\
\hline & & & & & & & \\
\hline Jarque-Bera & 30.06312 & 27.43801 & 12.28211 & 22.77998 & 55.41506 & 21.336994 & 29.71825 \\
\hline Probability & 0.000000 & 0.000000 & 0.002153 & 0.000011 & 0.000000 & 0.003478 & 0.000000 \\
\hline & & & & & & & \\
\hline Sum & 222.0300 & 527.0410 & 557.1000 & 447.6000 & 480.5500 & 319.000 & 337.1000 \\
\hline Sum Sq. Dev. & 471.7095 & $1.79 E+10$ & 11281.85 & 1196.010 & 4537.789 & 4365.025 & 1515.474 \\
\hline & & & & & & & 30 \\
\hline Observations & 30 & 30 & 30 & 30 & 30 & & 30 \\
\hline
\end{tabular}

Source: Computer Output Data using E-views 8.0 
The Effect of Financial Deepening on Economic Growth in Nigeria (1985 -2014).

\subsection{Result of Correlation Analysis}

Gujarati, Porte and Gunasekar, (2012)[40] state that if the correlation coefficient between two variables is in excess of 0.8 , multicollinearity is a problem. Multicollienearity, a phenomenon in statistics occurs when two or more independent variables within a stated model are confirmed to portray a great height of correlation with each other. When this happens, the estimated coefficient of the variables may be caused to vary intermittently when the model or data are modified. However, this study found no evidence of high or exact multicollinearity as all correlation coefficient are less than the 0.8 bench mark. Put differently, the result indicates absence of multicollinearity. This result is shown in the Table 6.3 below.

Table 6.3 Correlation Matrix for the Variable of the Study

\begin{tabular}{|l|c|l|l|l|l|l|l|}
\hline & GDPGR & M2 & OPEN & INF & FSR & MCR & PSCR \\
\hline GDPGR & 1.000000 & 0.189068 & 0.467504 & -0.081447 & 0.017816 & 0.300542 & 0.165583 \\
\hline M2 & 0.189068 & 1.000000 & 0.269058 & -0.222206 & 0.626884 & 0.514256 & 0.430643 \\
\hline OPEN & 0.467504 & 0.269058 & 1.000000 & -0.208547 & 0.034593 & 0.481690 & 0.172685 \\
\hline INF & -0.081447 & -0.222206 & -0.208547 & 1.000000 & -0.205183 & -0.351665 & 0.240043 \\
\hline FSR & 0.017816 & 0.626884 & 0.034593 & -0.205183 & 1.000000 & 0.627702 & 0.647723 \\
\hline MCR & 0.300542 & 0.514256 & 0.481690 & -0.351665 & 0.627702 & 1.000000 & 0.663290 \\
\hline PSCR & 0.165583 & 0.430643 & 0.172685 & -0.240043 & 0.647723 & 0.663290 & 1.000000 \\
\hline
\end{tabular}

Source: Computer output data using E-views 8.0

\subsection{Analysis of Result}

6.4.1. Result of Research Hypothesis One and Research Question One

Restatement of Research Hypothesis

$\mathbf{H}_{\mathbf{O}}$ : $\quad$ Money supply has no significant effect on economic growth in Nigeria.

\section{Restatement of Research Question}

How significant is the effect of money supply on economic growth in Nigeria?

The result in Table 6.4 unveiled that financial deepening measure-money supply ratio is statistically significant at 5\% level of significance. The coefficient of the constant 0.692466 implies that holding money supply, trade openness and inflation rate constant, the gross domestic product will increase by 0.692466 percent. Money supply, trade openness has a positive impact on gross domestic product while inflation rate exhibit negative relationship.

Table 6.4: Ordinary Least Square Regression Result for Model 1

Dependent Variable: Gross Domestic Product Growth Rate

\begin{tabular}{|c|c|c|c|c|}
\hline Variable & Coefficient & Std. Error & t-Statistic & Prob. \\
\hline $\mathrm{C}$ & 0.692466 & 5.016117 & 3.522086 & 0.0020 \\
\hline M2 & 0.488774 & 0.120110 & 2.593458 & 0.0030 \\
\hline OPEN & 0.231227 & 0.092568 & 3.281378 & 0.0002 \\
\hline INF & -0.111253 & 0.068367 & -1.253573 & 0.0410 \\
\hline R-squared & 0.534116 & \multicolumn{2}{|c|}{ Mean dependent var } & 4.400000 \\
\hline Adjusted R-squared & 0.503647 & \multicolumn{2}{|c|}{ S.D. dependent var } & 7.595234 \\
\hline S.E. of regression & 7.067605 & \multicolumn{2}{|c|}{ Akaike info criterion } & 6.872486 \\
\hline Sum squared resid & $7.30 \mathrm{E}+09$ & \multicolumn{2}{|c|}{ Schwarz criterion } & 7.059312 \\
\hline Log likelihood & -99.08729 & \multicolumn{2}{|c|}{ Hannan-Quinn criter. } & 10.503160 \\
\hline F-statistic & 10.14186 & \multirow{2}{*}{\multicolumn{2}{|c|}{ Durbin-Watson stat }} & 2.063649 \\
\hline Prob(F-statistic) & 0.000122 & & & \\
\hline
\end{tabular}

Source: Computer Output Data using E-views 8.0

The money supply ratio coefficient of 0.488774 suggests that a percentage increase in money supply ratio resulted in 0.488774 percent increase in gross domestic product growth rate, a proxy for economic growth within the period covered by the study. This supports the works of Onwumere et al (2012)[39] who have found that money supply ratio exert positive statistically significant effect on economic growth in Nigeria.

The multiple coefficient of determination $\left(\mathrm{R}^{2}\right)$ is approximately 0.53 , that is, the explanatory variable explained about $53 \%$ of the total variation in the dependent variable. Also, the adjusted $\mathrm{R}^{2}$ is about 0.50 that is $50 \%$ variation. It revealed that only $50 \%$ of changes in economic growth can be explained by the financial deepening proxies.

The critical value of F-distribution at 5\% level of significance and 26 degree of freedom, ie $F(4,26)$ is 2.74. F statistic calculated as divulged in Table 6.4 for model 1 is 10.14 . This value is greater than tabulated Fstatistics of 2.74 , and by implication the model is statistically significant and has a goodness of fit. We therefore reject the null hypothesis (Ho). Furthermore, the probability of the F statistics is 0.000122 the value is less than 0.05 (5\% level of significance). 
The Effect of Financial Deepening on Economic Growth in Nigeria (1985 -2014).

The calculated Durbin Watson $\left(\mathrm{d}^{*}\right)$ statistic for model 1 is 2.063649. The tabulated Durbin Watson for lower limit (dL) and upper limit (du) are 1.06 and 1.76 respectively. These values are lesser than calculated Durbin Watson $\left(\mathrm{d}^{*}\right)$.The calculated Durbin Watson of 2.063647 implies that there is no autocorrelation between gross domestic product growth rate and financial deepening proxies.

The regression output in Table 6.4 has illustrated the positive impact of money supply on economic growth. This authenticates the finance -led theory that financial deepening is the leading indicator of economic growth. In the light of this, the null hypothesis that money supply ratio to GDP has no significant effect on economic growth proxy by gross domestic product is rejected.

In terms of the research question of how significant is the effect of money supply ratio to GDP on economic growth, the result in Table 6.4 disclosed that the effect of money supply ratio to GDP on economic growth is statistically significant at $5 \%$ level of significance.

\subsubsection{Result of Research Hypothesis Two and Research Question Two Restatement of Research Hypothesis}

Ho: Private sector credit has no significant effect on economic growth of Nigeria.

\section{Restatement of Research Question}

What is the effect of private sector credit on economic growth in Nigeria?

The result in table 6.5 indicated that financial deepening measure - private sector credit ratio to GDP is statistically significant at $5 \%$ level of significance. The coefficient of the constant 0.671063 suggests that holding private sector credit ratio to GDP, trade openness and inflation rate constant, gross domestic product will appreciate by 0.671063 percent. Private sector credit ratio, trade openness has a positive relationship with gross domestic product while inflation rate exhibit negative relationship.

Table 6.5: Ordinary Least Square Regression Result for Model 2

Dependent Variable: Gross Domestic Product

\begin{tabular}{|c|c|c|c|c|}
\hline Variable & Coefficient & Std. Error & t-Statistic & Prob. \\
\hline $\mathrm{C}$ & 0.671063 & 4.979631 & 2.562036 & 0.0041 \\
\hline PSCR & 0.613361 & 0.197729 & 1.531915 & 0.0010 \\
\hline OPEN & 0.330201 & 0.068700 & 2.205688 & 0.0022 \\
\hline INF & -0.191213 & 0.090560 & -2.580891 & 0.0310 \\
\hline R-squared & 0.554216 & \multicolumn{2}{|c|}{ Mean dependent var } & 4.400000 \\
\hline Adjusted R-squared & 0.523347 & \multicolumn{2}{|c|}{ S.D. dependent var } & 7.595234 \\
\hline S.E. of regression & 7.051416 & \multicolumn{2}{|c|}{ Akaike info criterion } & 6.867900 \\
\hline Sum squared resid & 1292.784 & \multicolumn{2}{|c|}{ Schwarz criterion } & 7.054726 \\
\hline Log likelihood & -99.01849 & \multicolumn{2}{|c|}{ Hannan-Quinn criter. } & 9.463370 \\
\hline F-statistic & 8.548519 & \multicolumn{2}{|c|}{ Durbin-Watson stat } & 2.079460 \\
\hline Prob(F-statistic) & 0.000232 & & & \\
\hline
\end{tabular}

Source: Computer Output Data using E-views 8.0

The private sector credit ratio to GDP coefficient of 0.613361 suggests that a percentage increase in private sector credit ratio to GDP resulted in 0.613361 percent increase in gross domestic product growth rate, a proxy for economic growth within the period covered by the study. This supports the works of Bashiru (2013) [14] who have found that private sector credit ratio to GDP exert positive statistically significant effect on gross domestic product in Nigeria.

The multiple coefficient of determination $\left(\mathrm{R}^{2}\right)$ is approximately 0.55 , that is, the explanatory variables explained about $55 \%$ of the total variation in the dependent variable. We can say that the model is well fitted. Also, the adjusted $\mathrm{R}^{2}$ is about 0.52 that is, about $52 \%$ variation in the regress and is explained by the regressors.

The critical value of F-distribution at $5 \%$ level of significance and 26 degree of freedom, ie, $f(4,26)$, is 2.74. F- statistics calculated as divulged in table 6.5 for model 2 is 8.54 . The value is greater than tabulated Fstatistics of 2.74, and by implication, the models is statistically significant and has a goodness of fit. Furthermore, the probability of the F - statistics is 0.000020 . The value is less than $0.05(5 \%$ level of significance).

The calculated Durbin Watson $\left(\mathrm{d}^{*}\right)$ statistic for model 2 is 2.079460. The tabulated Durbin Watson for lower limit (dL) and upper limit (du) are 1.06 and 1.76 respectively. These values are lesser than calculated Durbin Watson $\left(\mathrm{d}^{*}\right)$. The calculated Durbin Watson of 2.079460 implies that there is no autocorrelation between gross domestic product growth rate and financial deepening proxies.

The regression output in table 6.5 has illustrated the positive effect of private sector credit ratio to GDP on economic growth. This authenticates the supply-leading hypothesis that financial deepening is the leading indicator of economic growth. The ordinary least square results in Table 6.5 revealed that private sector credit 
The Effect of Financial Deepening on Economic Growth in Nigeria (1985 -2014).

ratio to GDP has significant effect on gross domestic product. In the light of this, the null hypothesis that private sector credit ratio to GDP has no significant effect on economic growth is rejected.

In terms of the research question of how significant is the effect of private sector credit ratio to GDP on economic growth, the result in Table 6.5 disclosed that the impact of private sector credit ratio on economic growth is statistically significant at $5 \%$ level of significance.

\subsubsection{Result of Research Hypothesis Three and Research Question Three Restatement of Research Hypothesis}

Ho: Market capitalization has no significant effect on economic growth in Nigeria.

\section{Restatement of Research Question}

To what extent has market capitalization influenced economic growth in Nigeria?

The result in table 4.6 indicated that stock based financial deepening measure-market capitalization ratio to GDP is statistically significant at 5\% level of significance. The coefficient of the constant 0.634670 suggests that holding market capitalization ratio to GDP; trade openness and inflation rate constant, gross domestic product will appreciate by 0.634670 . Market capitalization ratio to GDP, trade openness and inflation rate has a positive relationship with gross domestic product

Table 6.6: Ordinary Least Square Regression Result for Model 3

Dependent Variable: Gross Domestic Product Growth Rate

\begin{tabular}{|l|l|l|l|l|}
\hline Variable & Coefficient & Std. Error & t-Statistic & Prob. \\
\hline C & 0.634670 & 4.374939 & 2.287942 & 0.0021 \\
\hline MCR & 0.650221 & 0.318359 & 0.551047 & 0.0011 \\
\hline OPEN & 0.215296 & 0.170198 & 0.252557 & 0.0313 \\
\hline INF & -0.217729 & 0.070295 & -2.146639 & 0.0030 \\
\hline & & & \\
\hline R-squared & 0.727847 & Mean dependent var & 4.400000 \\
\hline Adjusted R-squared & 0.638752 & S.D. dependent var & 7.595234 \\
\hline S.E. of regression & 7.048638 & Akaike info criterion & 6.867112 \\
\hline Sum squared resid & 1291.766 & Schwarz criterion & 7.053938 \\
\hline Log likelihood & -99.00667 & Hannan-Quinn criter. & 11.53058 \\
\hline F-statistic & 7.557361 & Durbin-Watson stat & 1.952165 \\
\hline Prob(F-statistic) & 0.000425 & \multicolumn{4}{|l}{} \\
\hline
\end{tabular}

Source: Computer Output Data using E-views 8.0

Market capitalization ratio to GDP coefficient of 0.650221 suggests that a percentage increase in market capitalization ratio to GDP resulted in 0.650221 percent increase in gross domestic product, a proxy for economic growth within the period covered by the study. This supports the works of Okoli (2010)[3] and Bashiru (2013)[14], who have found that market capitalization exert positive statistically significant effect on gross domestic product in Nigeria. However, it disagrees with Ownumere et al (2012) [39] that market capitalization ratio is negatively related with economic growth.

The multiple coefficient of determination $\left(\mathrm{R}^{2}\right)$ is approximately 0.72 , that is, the explanatory variables explained about $72 \%$ of the total variation in the dependent variable. We can say that the model is well fitted. Also, the adjusted $\mathrm{R}^{2}$ is approximately about 0.64 that is about $64 \%$ variation in the regress and is explained by the regressors.

The critical value of F-distribution at $5 \%$ level of significance and 26 degree of freedom, ie, $\mathrm{f}(4,26)$, is 2.74. F- statistics calculated as divulged in Table 6.6 for model 3 is 7.56. The value is greater than tabulated Fstatistics of 2.74, and by implication, the models is statistically significant and has a goodness of fit. Furthermore, the probability of the F - statistics is 0.000425 . The value is less than $0.05(5 \%$ level of significance).

The calculated Durbin Watson $\left(\mathrm{d}^{*}\right)$ statistic for model 3 is 1.952165. The tabulated Durbin Watson for lower limit $(\mathrm{dL})$ and upper limit $(\mathrm{du})$ are 1.06 and 1.76 respectively. These values are lesser than calculated Durbin Watson ( $\left.\mathrm{d}^{*}\right)$. The calculated Durbin Watson of 1.942165 implies that there is no autocorrelation between gross domestic product growth rate and financial deepening proxies.

The regression output in Table 6.6 has illustrated the positive effect of market capitalization ratio to GDP on economic growth. This authenticate the supply-leading hypothesis that financial deepening is the leading indicator of economic growth and validates the result of Okoli (2010)[3] and Bashiru (2013)[14] that Nigeria stock market has the potentials of growth inducing .

This result also supports the Mckinnon (1999)[41] complementary hypothesis that development of the financial and stock market can help the economy generate more savings and productive investment. 
The Effect of Financial Deepening on Economic Growth in Nigeria (1985 -2014).

The ordinary least square results in Table 4.6 revealed that market capitalization ratio to GDP has significant effect on gross domestic product. In the light of this, the null hypothesis that market capitalization ratio to GDP has no significant effect on economic growth is rejected.

In terms of the research question of how significant is the effect of market capitalization ratio to GDP on economic growth, the result in Table 6.6 disclosed that the effect of market capitalization ratio to GDP on economic growth is statistically significant at $5 \%$ level of significance.

\subsubsection{Result of Research Hypothesis Four and Research Question Four Restatement of Research Hypothesis}

Ho: Financial saving has no significant effect on economic growth in Nigeria.

\section{Restatement of Research Question}

To what level has financial savings stimulated economic growth in Nigeria?

The result in Table 6.7 indicated that financial deepening measure-financial saving ratio to GDP is statistically significant at 5\% level of significance. The coefficient of the constant 0.602444 suggests that holding financial saving ratio to GDP; trade openness and inflation rate constant, gross domestic product will appreciate by 0.602444 . Financial saving ratio has a positive relationship with gross domestic product while trade openness and inflation rate exhibit negative relationship.

Table 6.7: Ordinary Least Square Regression Result for Model 4

Dependent Variable: Gross Domestic Product

\begin{tabular}{|l|l|l|l|l|}
\hline Variable & Coefficient & Std. Error & t-Statistic & Prob. \\
\hline C & 0.602444 & 5.453550 & 2.027302 & 0.0004 \\
\hline FSR & 0.579662 & 0.330049 & 0.429274 & 0.0034 \\
\hline OPEN & 0.256800 & 0.168933 & 0.198643 & 0.0011 \\
\hline INF & -0.139969 & 0.090290 & -2.657749 & 0.0251 \\
\hline R-squared & 0.628855 & Mean dependent var & 4.400000 \\
\hline Adjusted R-squared & 0.608723 & S.D. dependent var & 7.595234 \\
\hline S.E. of regression & 7.089562 & Akaike info criterion & 6.878690 \\
\hline Sum squared resid & 1306.809 & Schwarz criterion & 7.065516 \\
\hline Log likelihood & -99.18035 & Hannan-Quinn criter. & 11.53058 \\
\hline F-statistic & 7.428155 & Durbin-Watson stat & 2.042124 \\
\hline Prob(F-statistic) & 0.000032 & & \\
\hline
\end{tabular}

Source: Computer Output Data using E-views 8.0

Financial saving ratio coefficient of 0.579662 suggests that a percentage increase in financial saving ratio resulted in 0.579662 increase in gross domestic product, a proxy for economic growth within the period covered by the study. This supports the works of Nzotta and Okereke (2013)[1] who have found that financial saving ratio to GDP is a useful explanatory variable for determining economic and exert positive statistically significant effect on gross domestic product in Nigeria.

The multiple coefficient of determination $\left(\mathrm{R}^{2}\right)$ is approximately 0.63 , that is, the explanatory variables explained about $63 \%$ of the total variation in the dependent variable. We can say that the model is fitted. Also, the adjusted $\mathrm{R}^{2}$ is about 0.61 that is, about $61 \%$ variation in the regress and is explained by the regressors.

The critical value of F-distribution at $5 \%$ level of significance and 26 degree of freedom, ie, $\mathrm{f}(4,26)$, is 2.74. F- statistics calculated as divulged in Table 6.7 for model 4 is 7.428155 . The value is greater than tabulated F-statistics of 2.74, and by implication, the models is statistically significant and has a goodness of fit. Furthermore, the probability of the F - statistics is 0.000032 . The value is less than 0.05 (5\% level of significance).

The calculated Durbin Watson $\left(\mathrm{d}^{*}\right)$ statistic for model 4 is 2.042124. The tabulated Durbin Watson for lower limit (dL) and upper limit (du) ) are 1.06 and 1.76 respectively. These values are lesser than calculated Durbin Watson $\left(\mathrm{d}^{*}\right)$. The calculated Durbin Watson of 2.042124 implies that there is no autocorrelation between gross domestic product growth rate and financial deepening proxies.

The regression output in table 6.7 has illustrated the positive effect of financial saving ratio to GDP on economic growth. This authenticates the supply-leading hypothesis that financial deepening is the leading indicator of economic growth.

The ordinary least square results in Table 6.7 revealed that financial saving ratio to GDP has significant effect on gross domestic product. In the light of this, the null hypothesis that financial saving ratio to GDP has no significant effect on economic growth is rejected. 
The Effect of Financial Deepening on Economic Growth in Nigeria (1985 -2014).

In terms of the research question of to what level has financial saving ratio to GDP stimulated economic growth in Nigeria, the result in Table 6.7 inferred that financial saving ratio to GDP has influenced economic growth by $54 \%$.

\subsection{A Priori Expectation for the Various Models}

As stated earlier in section five, the result or parameter estimates of the models will be interpreted on the basis of the supposed signs of the parameters as established by the theory on which this research work is based.

Table 6.8: A Priori Expectation for model 1

Dependent Variable: Gross Domestic Product

\begin{tabular}{|l|l|l|l|}
\hline Independent Variables & Expected Signs & Observed Signs & Remarks \\
\hline Money supply ratio to GDP & + & + & Conformed \\
\hline Trade openness & + & + & Conformed \\
\hline Inflation rate & - & - & Conformed \\
\hline
\end{tabular}

Source: Ordinary Least Square Regression Result in Table 6.4

Table 6.9: A Priori Expectation for model 2

Dependent Variable: Gross Domestic Product

\begin{tabular}{|l|l|l|l|}
\hline Independent Variables & Expected Signs & Observed Signs & Remarks \\
\hline Private sector credit ratio to GDP & + & + & Conformed \\
\hline Trade openness & + & + & Conformed \\
\hline Inflation rate & - & - & Conformed \\
\hline
\end{tabular}

Source: Ordinary Least Square Regression Result in Table 6.5

Table 6.10: A Priori Expectation for model 3

Dependent Variable: Gross Domestic Product

\begin{tabular}{|l|l|l|l|}
\hline Independent Variables & Expected Signs & Observed Signs & Remarks \\
\hline Market capitalization ratio to GDP & + & + & Conformed \\
\hline Trade openness & + & + & Conformed \\
\hline Inflation rate & - & - & Conformed \\
\hline
\end{tabular}

Source: Ordinary Least Square Regression Result in Table 6.6

Table 6.11: A Priori Expectation for model 4

Dependent Variable: Gross Domestic Product

\begin{tabular}{|l|l|l|l|}
\hline Independent Variables & Expected Signs & Observed Signs & Remarks \\
\hline Financial saving ratio to GDP & + & + & Conformed \\
\hline Trade openness & + & + & Conformed \\
\hline Inflation rate & - & - & Conformed \\
\hline
\end{tabular}

Source: Ordinary Least Square Regression Result in Table 6.7

The results of the regression based on the ordinary least square approach are presented in Tables 6.4, 6.5, 6.7 and 6.8. The results were used to check the conformity of our prior expectation. In terms of a priori expectations, for model one, two, three and four there is a positive relationship between financial deepening and economic growth. The financial deepening variables, money supply ratio to GDP, Private sector credit ratio to GDP, market capitalization ratio to GDP and Financial saving to GDP was found to have conformed to our a priori expectation. The supply leading hypothesis contends that savings accumulation, transfer of resources to growth inducing sectors and expanding of liquidity promote economic growth.

The control variable trade openness has positive impact on economic growth. According to DeGregorio \& Guidotti (1995)[42], higher productivity leads to higher volume of investment which promote economic growth. Inflation rate was also seen to have negative significant impact on economic growth. This conformed with our a priori expectation.

\subsection{Discussion of Findings}

This study examined the effect of financial deepening on economic growth in Nigeria from 1985 -2014. Following a detailed time series analysis the findings revealed a plausible result on economic growth in Nigeria. Money supply ratio to GDP had a positive and significant effect on economic growth. This implies that a high money supply deepen the financial sector which promote economic growth. Money supply can create economic stimulus resulting to corporate earnings and effective supply of money to the best investments, will in turn lead to increased productivity and potentially faster economic growth. This was consistent with the findings of Nzotta et al (2009)[1]. 
From the result, financial saving ratio to GDP had a positive significant effect on economic growth. This implies that financial liberalization is likely to lead to an increase in interest rates which would, in turn, increase the rate of saving as people will now be encouraged to save in banks. With increased financial savings, banks are more likely to increase their supply of loan-able funds. Effective allocation of savings to the best investment will lead to increased productivity and potentially faster economic growth. This support the findings of Nzotta and Okereke (2009)[1].

The control variable Trade openness was also found to exert a positive effect on economic growth. Economies that are open are generally in a better position to adopt new technologies and new ideas from the rest of the world. In addition, they are likely to have a greater division of labour and production processes that are more consistent with their comparative advantages, which enable them to grow faster. Trade lets an economy make better use of its resources, by allowing imports of goods and services at a lower cost than they could be produced at home. Increase in trade openness will provide developing countries like Nigeria with access to investment and intermediate goods that are vital to its development processes. This was consistent with the findings of Adu et al (2013)[35]. Meanwhile inflation rate which is used as a control variable and other growth determinant in the regression indicate a negative effect on economic growth. Inflation uncertainty reduces efficiency by discouraging long-term contracts and increasing relative price variability. A high and unpredictable rate of inflation generally results in poor performance of businesses and households. This conform with the findings of Nzotta and Okereke (2009)[1] and Adu et al (2013)[35].

\section{Conclusion}

The finance-growth nexus has captured the interest of development practitioners, finance experts and researchers as well as policy makers in recent times given the turbulent experiences of the financial world and its accompanying consequences.

This study examined financial deepening (stock based, bank based) and economic growth in Nigeria from 1985 to 2014 using ordinary least square approach. The specific objectives were to estimate the impact of financial deepening measures on economic growth in Nigeria. In the process of doing this, the hypotheses that financial deepening promotes economic growth in Nigeria were validated.

This study, in line with the theoretical literature, revealed a positive influence of financial deepening as measured by money supply ratio to GDP, private sector credit ratio to GDP, market capitalization ratio to GDP and financial savings ratio to GDP on economic growth of Nigeria. In the light of the above and the debate over the finance-growth nexus, the findings of this study should not be viewed as conclusive empirical evidence, but rather an additional motivation for further research in the area with regards to the use of indicators of financial deepening.

\section{Recommendations}

Taking cognizance of the findings from the study, the following recommendations are proposed.

* The study recommends that policy makers should design policies which will promote the bank and capital markets, remove the obstacles that impede their growth and strengthen the healthy and competitiveness of the banking system.

* Evidence suggests stock market liquidity encourages economic growth, therefore this study recommends that policy makers should consider reducing impediments to liquidity in the stock market. Easing restrictions on international capital and entry into the market to ensure that more companies are listed.

* The study recommends that policy makers should regularly address reported cases of abuse and other sharp practices by bank officials and stock market participants as there is need to ensure confidence in the bank and stock market so as to enhance growth.

\section{Journal Papers}

\section{References}

[1]. Nzotta, S.M. \& Okereke, E.J. (2009). Financial Deepening and Economic Development in Nigeria: An Empirical Investigation African Journal of Accounting, Economics, Finance and Banking Research, 5(5), 52-66.[1]

[2]. Arestis, A., Demetriades, P. \& Luintel, K. (2001). Financial Development and Economic Growth: The Role of Stock Markets, Journal of Money, Credit and Banking, 33(1), 16 - 41.[2]

[3]. Okoli M N(2010) Evaluating the Nexus between Financial Deepening and Stock Market in Nigeria. European Scientific Journal Vol. 4 No, 2 [3]

[4]. Neusser, K., \& Kugler, M. (1998). Manufacturing growth and financial development: Evidence from OECD countries. Review of Economics and Statistics, 80(4), 638 - 646. [4]

[5]. Patrick, H. T., (1966). Financial Development and Economic Growth in Underdeveloped Countries, Economic Development and Cultural Change, 14, 174-189.[5]

[6]. Ireland, P. N. (1994). Money and Growth: An Alternative Approach. American Economic Review, March, 47-65.[6]

[7]. Odhiambho, N. M (2004) Financial Development and Economic Growth in South Africa. Department of Economics, University of Fort Hare, South Africa.[7] 
[8]. Wadud, M. A. (2005). Financial Development and Economic Growth: A Cointegration and ECM Approach for South Asian Countries, Paper presented at International Conference of the Asian Law and Economics Association at Seoul National University, South Korea on 24-25 June, 2005.[8]

[9]. Ndebbio, J.E. (2004). Financial deepening, economic growth and development: Evidence from selected Sub-Saharan African countries. African Economic Research Consortium, Nairobi. Research Paper 142, August.[9]

[10]. Agu, C. C., \& Chukwu, O. J. (2008). Toda and Yamamoto causality tests between bank-based financial deepening and economic growth in Nigeria. European Journal of Social Sciences, 7(2), 189-198.[10]

[11]. Victor, O.and Samuel, E. (2014). An Empirical Assessment of Financial Deepening and Economic Growth in Nigeria. International Review of Management and Business Research, 3(1), 139 - 149. [11]

[12]. Huizinga (2000) Finance and the Sources of Growth

[13]. Osho, A. E. (2014). The Role of Stock Market in Nigeria's Economic Development, International Journal of Scientific and Research Publication,4(4), 1-7.[13]

[14]. Bashiru I. (2013). Financial Deepening and Economic Growth: Evidence from Ghana. University of Cape Coast, M. Sc Thesis Submitted to the Department of Economic, University of Cape Coast, and Ghana.[14]

[15]. Levine, R. (2002). Bank-Based or Market-based Financial Systems: which is Better? Journal of Financial International, 11(4), 398428.[15]

[16]. Jalilian H.and Kirkpatrick C. (2005) Does Financial Development Contribute to Poverty Reduction. The Journal of Develoment Studies Volume 41, Iissue 4, 2005[16]

[17]. Sahoo, S. (2013). Financial Structures and Economic Development in India: An Empirical Evaluation, RBI Working Paper No.02, Department of Economic and Policy Research, Reserve Bank of India, Mumbai [17]

[18]. Waqabaca, C. (2004). Financial development and economic growth in Fiji. Working Paper 2004/03. Economics Department Reserve Bank of Fiji.[18]

[19]. Azege, M. (2004). The Impact of Financial Intermediation on Economic Growth:The Nigerian Perspective, in Central Bank of Nigeria bullion publication (2009).[19]

[20]. Sulaiman, L.A., Oke, M.O. \& Azeez, B.A. (2012). Effect of Financial Liberalization on Economic Growth of Developing Countries: The Nigerian Experience International Journal of Economics and Management Sciences, 1(12), 16-28.[20]

[21]. Ardic, O. P. and Damar, H. E. (2006). Financial Sector Deepening and Economic Growth: Evidence From Turkey www.google.com.ng.[21]

[22]. Guryay,E., Safakli, O. V. and Tuzel, B. (2007). Financial Development and Economic Growth: Evidence from Northern Cyprus, International Research Journal of Finance and Economics, Issue 8.[22]

[23]. King, R. G., and Levine, R. (1993a). Finance and growth: Schumpeter might be right. Quarterly Journal of Economics, 108, 713737.[23]

[24]. Nguena, C. L., and Abimbola, T. (2013). Financial Deepening Dynamics and Implication for Financial Policy Coordination in a Monetary Union: the case of WAEMU. African Economic Conference 2013 Regional Integration. Johannesburg, South Africa.[24]

[25]. Jalil, A., Wahid A. N., \& Shahbaz, M. (2010). Financial Deepening and Growth: A Positive, Monotonic Relationship? Empirical Evidences from South Africa. Retrieved from http://mpra.ub.uni-muenchen.de/27668/. [25]

[26]. Onuonga, M. S.(2014). Financial Development and Economic Growth in Kenya: An Empirical Analysis 1980-2011. International Journal of Economics and Finance; Vol. 6, No 7. [26]

[27]. Nwogwugwu. I C (2008). Stock Market Development and Economic Growth in Nigeria: The Causal Linkage. Nigerian Journal of Securities and Finance. 13 (1), 115-128. [27]

[28]. World Bank. (2010). World development indicators on online (WDI) database, Washington, DC: World Bank Retrieved September 2010, http://www.worldbank.org.[28]

[29]. Antwi, S., Mills, E. F. A., \& Zhao, X. (2013). Impact of Macroeconomic Factors on Economic Growth in Ghana: A Cointegration Analysis. International Journal of Academic Research in Accounting, Finance and Management Sciences, 3(1), 3545.[29]

[30]. Kanu, S. I. and Ozurumba, B. A. (2013). Migrant's Remittanges and Economic Growth In sub Saharan Africa: Evidence from Nigeria, Ghana and South Africa. Interdisciplinary Journal of Contemporary Research in Business,4(10) 534-550.[30]

[31]. Fisher, S. (2001). The Importance of Financial Markets in Economic Growth: Memo, The Brazilian Mercantile and Futures Exchange, Citigroup, Campos do Jordao, Brazil [31]

[32]. Ghani, (2002) Openness and Economic Growth in Pakistan. The Pakistan Development Review. 42:4 Part 11(Winter 2002) pp. 795-807[32]

[33]. Fatima A. M (2004) Does Financial Development Cause Economic Growth? An Empirical Investigation Drawing On The Moroccan Experience. www.researchgate.net[33]

[34]. Ang, J.B and Mckibbin W (2007) Financial Liberalization, Financial Sector Development And Growth; Evidence from Malaysia. Journal Of Development Economics, Vol 84 issue 1 pp215-233[34]

[35]. Adu, Marbuah and Mensah (2013) Financial development and Economic Growth in Ghana: Does the measure of financial development matter, The Journal of Development Finance, 3 192-203 [35]

[36]. Luqman S. (2014) Financial Deepening and Economic Growth in Pakistan: An application of Cointegration and VECM Approach. Interdisciplinary Journal of Contemporary Research in Business. Vol 5, No 12 April 2014[36]

[37]. Shittu, A. I. (2012). Financial Intermediation and Economic Growth in Nigeria, British Journal of Arts and Social Sciences, 4 (2).[37]

[38]. Sulaiman L.and AzzezB. (2012) The Effect of External Debt on Economic Growth of Nigeria. Journal of Economies and Sustainable Development. www.iiste.org 3(8) [38]

[39]. Onwumere, Ibe, Ozoh and Mounanu (2012) The Impact Of Financial Deepening On Economic Growth: Evidence From Nigeria. Research Journal Of Finance And Accounting, Vol 3. No 10[39]

[40]. De Gregorio, J., and Guidotti,P. E.(1995). Financial Development and Economic Growth. World Development, 23, 433-448. [42]

Books

[41] Gujarati N., Porte C and Gunasekar S. (2012). Basic Econometrics (5 ${ }^{\text {th }}$ Edition ed.). New York:Tata McGraw-Hill [40]

[42] MacKinnon, J.G. (1999). Critical Values for Cointegration Tests. In R.F. Engle and C.W.J. Granger (eds.). Long-Run Economic Relationships: Readings in Cointegration. Oxford: Oxford University Press.[41] 
The Effect of Financial Deepening on Economic Growth in Nigeria (1985 -2014).

\section{Appendix 1}

Financial Deepening And Economic Growth Indicators (1985 -2014)

\begin{tabular}{|c|c|c|c|c|c|c|c|}
\hline YEAR & $\begin{array}{l}\text { GDP at } \\
\text { Growth } \\
\text { Rate } \\
(\%)\end{array}$ & $\begin{array}{l}\text { Money } \\
\text { Supply as } \\
\text { a Ratio of } \\
\text { GDP }(\%)\end{array}$ & $\begin{array}{l}\text { Private Sector } \\
\text { Credit as a } \\
\text { Ration of GDP } \\
(\%)\end{array}$ & $\begin{array}{l}\text { Market } \\
\text { Capitalization } \\
\text { as a Ratio of } \\
\text { GDP }(\%)\end{array}$ & $\begin{array}{l}\text { Financial } \\
\text { Savings as a } \\
\text { Ratio of GDP } \\
(\%)\end{array}$ & $\begin{array}{l}\text { Inflation } \\
(\%)\end{array}$ & $\begin{array}{l}\text { Trade } \\
\text { Openness } \\
(\%)\end{array}$ \\
\hline 1985 & -7.8 & 16.6 & 9.7 & 4.90 & 9.30 & 1.00 & 13.97 \\
\hline 1986 & -8.8 & 17.7 & 11.3 & 5.05 & 10.35 & 13.7 & 11.07 \\
\hline 1987 & -10.8 & 14.3 & 10.9 & 4.5 & 9.67 & 9.7 & 24.96 \\
\hline 1988 & 7.5 & 14.6 & 10.4 & 3.80 & 8.83 & 61.2 & 19.98 \\
\hline 1989 & 6.5 & 12.0 & 8.0 & 3.35 & 6.23 & 44.7 & 23.22 \\
\hline 1990 & 12.8 & 11.2 & 7.1 & 4.96 & 6.27 & 3.6 & 47.35 \\
\hline 1991 & 0.6 & 13.8 & 7.6 & 4.23 & 6.92 & 23 & 38.67 \\
\hline 1992 & 0.4 & 12.7 & 6.6 & 3.56 & 6.30 & 48.8 & 39.85 \\
\hline 1993 & 2.1 & 15.2 & 11.7 & 4.36 & 7.80 & 61.3 & 35.28 \\
\hline 1994 & 0.9 & 16.5 & 10.2 & 4.74 & 7.93 & 76.8 & 26.35 \\
\hline 1995 & -0.3 & 9.9 & 6.2 & 6.20 & 3.73 & 51.6 & 58.67 \\
\hline 1996 & 5.0 & 8.6 & 5.9 & 7.09 & 3.34 & 14.3 & 46.43 \\
\hline 1997 & 2.8 & 9.9 & 7.5 & 6.73 & 4.24 & 10.2 & 49.83 \\
\hline 1998 & 2.7 & 12.2 & 8.8 & 6.58 & 5.01 & 11.9 & 39.84 \\
\hline 1999 & 0.5 & 13.4 & 9.2 & 6.41 & 5.93 & 0.2 & 43.84 \\
\hline 2000 & 5.3 & 13.1 & 7.9 & 7.03 & 5.74 & 14.5 & 43.65 \\
\hline 2001 & 4.4 & 18.4 & 11.1 & 9.61 & 7.08 & 16.5 & 46.79 \\
\hline 2002 & 3.8 & 19.3 & 11.9 & 9.81 & 7.60 & 12.2 & 41.78 \\
\hline 2003 & 10.4 & 19.7 & 11.1 & 13.71 & 6.61 & 23.8 & 52.13 \\
\hline 2004 & 33.7 & 18.7 & 12.5 & 18.51 & 6.99 & 10 & 57.75 \\
\hline 2005 & 3.4 & 18.1 & 12.6 & 19.85 & 9.01 & 11.6 & 68.77 \\
\hline 2006 & 8.2 & 20.5 & 12.3 & 27.58 & 9.37 & 8.5 & 56.20 \\
\hline 2007 & 6.8 & 24.8 & 17.8 & 63.81 & 13.04 & 6.6 & 59.16 \\
\hline 2008 & 6.3 & 33.0 & 28.5 & 39.36 & 16.95 & 15.1 & 63.19 \\
\hline 2009 & 6.9 & 38.0 & 36.7 & 28.36 & 23.25 & 13.9 & 54.52 \\
\hline 2010 & 7.8 & 20.4 & 18.7 & 18.30 & 10.98 & 18.8 & 35.65 \\
\hline 2011 & 4.9 & 19.2 & 16.9 & 16.24 & 10.33 & 10.3 & 39.61 \\
\hline 2012 & 4.3 & 19.5 & 20.6 & 20.79 & 11.33 & 12.0 & 33.46 \\
\hline 2013 & 5.4 & 18.9 & 19.7 & 23.78 & 10.79 & 8.0 & 29.48 \\
\hline 2014 & 6.3 & 19.9 & 19.2 & 18.95 & 13.49 & 8.0 & 20.75 \\
\hline
\end{tabular}

Source: Compiled from data obtained from Central Bank of Nigeria Statistical Bulletin 2014

\section{Appendix 2}

Regression Results Model One

\begin{tabular}{|c|c|c|c|c|}
\hline \multicolumn{3}{|c|}{ Dependent Variable: GDP } & & \\
\hline \multicolumn{3}{|l|}{ Method: Least Squares } & & \\
\hline \multicolumn{3}{|c|}{ Date: $05 / 22 / 16$ Time: $20: 25$} & & \\
\hline \multicolumn{3}{|c|}{ Sample: 19852014} & & \\
\hline \multicolumn{3}{|c|}{ Included observations: 30} & & \\
\hline Variable & Coefficient & Std. Error & t-Statistic & Prob. \\
\hline $\mathrm{C}$ & 0.692466 & 5.016117 & 3.522086 & 0.0020 \\
\hline M2 & 0.488774 & 0.120110 & 2.593458 & 0.0030 \\
\hline OPEN & 0.231227 & 0.092568 & 3.281378 & 0.0002 \\
\hline INF & -0.111253 & 0.068367 & -1.253573 & 0.0410 \\
\hline R-squared & 0.534116 & Mean dependent var & & 4.400000 \\
\hline Adjusted R-squared & 0.503647 & S.D. dependent var & & 7.595234 \\
\hline S.E. of regression & 7.067605 & Akaike info criterion & & 6.872486 \\
\hline Sum squared resid & $7.30 \mathrm{E}+09$ & Schwarz criterion & & 7.059312 \\
\hline Log likelihood & -99.08729 & Hannan-Quinn criter. & & 10.503160 \\
\hline F-statistic & 10.14186 & Durbin-Watson stat & & 2.063649 \\
\hline Prob(F-statistic) & 0.000122 & & & \\
\hline
\end{tabular}


The Effect of Financial Deepening on Economic Growth in Nigeria (1985 -2014).

\section{Model Two}

\begin{tabular}{|c|c|c|c|c|}
\hline \multicolumn{5}{|c|}{ Dependent Variable: GDP } \\
\hline \multirow{2}{*}{\multicolumn{5}{|c|}{ Method: Least Squares }} \\
\hline & & & & Date: $05 / 22 / 16$ Time: $20: 25$ \\
\hline \multicolumn{5}{|l|}{ Sample: 19852014} \\
\hline \multicolumn{5}{|c|}{ Included observations: 30} \\
\hline Variable & Coefficient & Std. Error & t-Statistic & Prob. \\
\hline & & & & \\
\hline $\mathrm{C}$ & 0.671063 & 4.979631 & 2.562036 & 0.0041 \\
\hline PSCR & 0.613361 & 0.197729 & 1.531915 & 0.0010 \\
\hline OPEN & 0.330201 & 0.068700 & 2. 205688 & 0.0022 \\
\hline INF & -0.191213 & 0.090560 & -2.580891 & 0.0310 \\
\hline R-squared & 0.554216 & Mean dependent var & & 4.400000 \\
\hline Adjusted R-squared & 0.523347 & S.D. dependent var & & 7.595234 \\
\hline S.E. of regression & 7.051416 & Akaike info criterion & & 6.867900 \\
\hline Sum squared resid & 1292.784 & Schwarz criterion & & 7.054726 \\
\hline Log likelihood & -99.01849 & Hannan-Quinn criter. & & 9.463370 \\
\hline F-statistic & 8.548519 & Durbin-Watson stat & & 2. 079460 \\
\hline Prob(F-statistic) & 0.000232 & & & \\
\hline
\end{tabular}

\section{Model Three}

\begin{tabular}{|c|c|c|c|c|}
\hline \multicolumn{5}{|c|}{ Dependent Variable: GDP } \\
\hline \multicolumn{5}{|c|}{ Method: Least Squares } \\
\hline \multicolumn{5}{|c|}{ Date: $05 / 22 / 16$ Time: $20: 25$} \\
\hline \multicolumn{5}{|l|}{ Sample: 19852014} \\
\hline \multicolumn{5}{|c|}{ Included observations: 30} \\
\hline Variable & Coefficient & Std. Error & t-Statistic & Prob. \\
\hline $\mathrm{C}$ & 5.634670 & 4.374939 & 2.287942 & 0.0021 \\
\hline MCR & 0.650221 & 0.318359 & 0.551047 & 0.0011 \\
\hline OPEN & 0.215296 & 0.170198 & 0.252557 & 0.0313 \\
\hline INF & -0.217729 & 0.070295 & -2.146639 & 0.0030 \\
\hline R-squared & 0.727847 & Mean dependent var & & 4.400000 \\
\hline Adjusted R-squared & 0.638752 & S.D. dependent var & & 7.595234 \\
\hline S.E. of regression & 7.048638 & Akaike info criterion & & 6.867112 \\
\hline Sum squared resid & 1291.766 & Schwarz criterion & & 7.053938 \\
\hline Log likelihood & -99.00667 & Hannan-Quinn criter. & & 11.53058 \\
\hline F-statistic & 7.557361 & Durbin-Watson stat & & 1.952165 \\
\hline Prob(F-statistic) & 0.000425 & & & \\
\hline
\end{tabular}

\section{Model Four}

\begin{tabular}{|c|c|c|c|c|}
\hline \multicolumn{5}{|c|}{ Dependent Variable: GDP } \\
\hline \multicolumn{5}{|c|}{ Method: Least Squares } \\
\hline \multicolumn{5}{|c|}{ Date: $05 / 22 / 16$ Time: $20: 26$} \\
\hline \multicolumn{5}{|c|}{ Sample: 19852014} \\
\hline \multicolumn{5}{|c|}{ Included observations: 30} \\
\hline Variable & Coefficient & Std. Error & t-Statistic & Prob. \\
\hline $\mathrm{C}$ & 5.602444 & 5.453550 & 2.027302 & 0.0004 \\
\hline FSR & 0.579662 & 0.330049 & 0.429274 & 0.0034 \\
\hline OPEN & 0.256800 & 0.168933 & 0.198643 & 0.0011 \\
\hline INF & -0.139969 & 0.090290 & -2.657749 & 0.0251 \\
\hline R-squared & 0.628855 & Mean dependent var & & 4.400000 \\
\hline Adjusted R-squared & 0.608723 & S.D. dependent var & & 7.595234 \\
\hline S.E. of regression & 7.089562 & Akaike info criterion & & 6.878690 \\
\hline Sum squared resid & 1306.809 & Schwarz criterion & & 7.065516 \\
\hline Log likelihood & -99.18035 & Hannan-Quinn criter. & & 11.53058 \\
\hline F-statistic & 7.428155 & Durbin-Watson stat & & 2.042124 \\
\hline Prob(F-statistic) & 0.000032 & & & \\
\hline
\end{tabular}


The Effect of Financial Deepening on Economic Growth in Nigeria (1985 -2014).

\section{Appendix 3}

\section{Correlation Analysis}

\begin{tabular}{|l|l|l|l|l|l|l|c|}
\hline & GDPGR & M2 & OPEN & INF & FSR & MCR & PSCR \\
\hline GDPGR & 1.000000 & 0.189068 & 0.467504 & 0.081447 & 0.017876 & 0.300542 & 0.165583 \\
\hline M2 & 0.189068 & 1.000000 & 0.269058 & -0.222206 & 0.626884 & 0.514256 & 0.430643 \\
\hline OPEN & 0.467504 & 0.269058 & 1.000000 & -0.208547 & 0.034593 & 0.481690 & 0.172685 \\
\hline INF & -0.081447 & -0.222206 & -0.208547 & 1.000000 & -0.205183 & -0.351665 & 0.240043 \\
\hline FSR & 0.017816 & 0.626884 & 0.034593 & -0.205183 & 1.000000 & 0.627702 & 0.647723 \\
\hline MCR & 0.300542 & 0.514256 & 0.481690 & -0.351665 & 0.627702 & 1.000000 & 0.663290 \\
\hline PSCR & 0.165583 & 0.430643 & 0.172685 & -0.240043 & 0.647723 & 0.663290 & 1.000000 \\
\hline
\end{tabular}

\section{Appendix 4}

\section{Descriptive Statistic Table}

\begin{tabular}{|l|l|l|l|l|l|l|l|}
\hline & FSR & GDPGR & INF & M2 & MCR & OPEN & PSCR \\
\hline Mean & 8.813667 & 4.400000 & 20.72667 & 17.33667 & 13.73833 & 24.36000 & 12.95333 \\
\hline Median & 7.865000 & 4.650000 & 12.95000 & 17.150000 & 7.060000 & 13.84000 & 11.10000 \\
\hline Maximum & 23.25000 & 33.70000 & 76.80000 & 38.00000 & 63.81000 & 68.77000 & 36.70000 \\
\hline Minimum & 3.340000 & -10.80000 & 0.200000 & 8.600000 & 3.350000 & 11.07000 & 5.900000 \\
\hline Std. Dev. & 4.075660 & 7.595234 & 19.94081 & 6.289426 & 13.19892 & 13.51701 & 6.879341 \\
\hline Skewness & 1.650449 & 1.454119 & 1.484466 & 1.530336 & 1.126956 & 1.541550 & 1.788640 \\
\hline Kurtosis & 6.626922 & 9.123117 & 4.005551 & 5.975949 & 8.122137 & 6.332279 & 6.313256 \\
\hline & & & & & & & \\
\hline Jarque-Bera & 30.06312 & 27.43801 & 12.28211 & 22.77998 & 55.41506 & 21.33694 & 29.71825 \\
\hline Probability & 0.000000 & 0.000000 & 0.002153 & 0.000011 & 0.000000 & 0.003478 & 0.000000 \\
\hline & & & & & & & \\
\hline Sum & 220.0300 & 527.0410 & 557.1000 & 447.6000 & 480.5500 & 319.000 & 337.1000 \\
\hline Sum Sq. Dev. & 471.7095 & $1.79 \mathrm{E}+10$ & 11281.85 & 1096.010 & 4517.789 & 4365.025 & 1515.474 \\
\hline & & & & & & & \\
\hline Observations & 30 & 30 & 30 & 30 & 30 & 30 & 30 \\
\hline
\end{tabular}

